\title{
Research on Feasibility of Controlling Crack Resistance of the Concrete Expanded-Plates Pile Under Vertical Tension
}

\author{
Qian Yongmei*, Wang Xu and Wang Ruozhu
}

Jilin Jianzhu University, Changchun, Jilin, 130118, P.R. China

\begin{abstract}
The paper introduces the developing situation and trend of the CEP piles in domestic and overseas at present. It is analyzed that the problem of crack resistance of the CEP pile used as uplift piles, by setting the prestressed steel, it is propose that the method of controlling pile crack resistance. For further, a reliable theoretical supporting is provided that study the uplift bearing capacity of the CEP piles.
\end{abstract}

Keywords: Crack, crack resistance, feasibility, prestressed steel, the concrete expanded-plates pile (The CEP pile).

\section{INTRODUCTION}

Along with the increasing of the national economy, the continuous development of city construction, the development and utilization of underground space, the addition of construction projects with different functional types, the buildings or structures foundation under vertical force is also increasing. Such as the foundation of chimney, television tower and any other tower structure, anchor pile foundation of cableway bridge or suspension bridge or cable-stayed bridge, the foundation of subway station and underground square and underground garage and underground commercial street and any other underground engineering and civil air defense projects, the abutment, offshore platform of drilling oil, coastal engineering, dock floor for building a ship, the foundation of high voltage transmission line tower, and liquefied foundation and building foundation under horizontal load, etc. In many case, it is in a specific environment conditions, so the original bearing compression pile may bear tension. At present, because of the special structural form itself of the concrete expanded-plates pile, of which can be used as an effective way to improve the bearing capacity under vertical tension.

\section{THE RESEARCH CURRENT SITUATION OF THE CEP PILE IN DOMESTIC AND FOREIGN}

In nearly decade, more attention was given to the CEP pile, however, the research on the CEP pile is still in the initial exploration stage, it is lesser that research reports of the CEP pile in domestic and foreign, and is rarely studied that especially research on bearing mechanism of the CEP pile and the uplift ultimate bearing capacity. However, with the CEP pile has been applied in uplift resistance engineering, especially the lack of theoretical research about uplift pile is more outstanding. The current research on the mechanism of uplift bearing capacity is concentrated in the aspects of load characteristics and load transfer law of pile, they hasn't

\footnotetext{
*Address correspondence to this author at the School of Civil Engineering, Jilin Jianzhu University, Changchun, 130118, P.R. China;

Tel: 13504405206; E-mail: 654675316@qq.com
}

enough clearly know that the work together between pile and soil under the vertical tension, the failure behavior of soil and the ultimate bearing capacity, etc. all of above are to be strengthened and deepened, especially the uplift bearing capacity is always the different problem of engineering design, thus it is greatly limited that the widely use of this type pile used as uplift resistance foundation.

Compared with the compressive bearing capacity of the CEP pile, it is relative larger lag that the related research on piles under vertical tension, at present, there are one problems of understanding and study on uplifting bearing capacity of the CEP pile [1]. First, it is lack that the basis of deep research on the design theory, there is no more clear rules for specifications about calculating uplift bearing capacity, in most cases, which can be defined according to the static load test in the site, but it is not allowed to load to damage when testing engineering piles, so it is hard to get the ultimate load magnitude, which to be maken an estimate only through simulation and calculation method. When testing the test pile, due to underestimate of the ultimate bearing capacity, the magnitude of test has reached its maximum load, but it have not been damaged, so it is unable to determine the limited bearing capacity of single pile [2]. Therefore, work together situation between pile and soil, and the failure mechanism of soil under the plate, should be careful analyzed, after full considering the effects above, it should be determined that calculating model of the ultimate uplift bearing capacity. Second, for diameter, spacing, position, grade, quantity and other factors of bearing explended-plate, which effect single pile bearing capacity, now, it has no reliable theoretical basis to support, and no further research of the above factors, at the same time, the failure character and confined condition of soil surrounding the CEP pile under uplife is also different from it under compresion, so the influence of aove parameters for the failure behavior of soil is also different. Theredfore, if the above parameters are determined just by engineering experience in the design, it will inevitably produce unreasonable design or wasteful, the advantage for bearing uplife capacity of the CEP pile will be greatly influenced. 
It is known that the above introduction about domestic and external developing situation of the CEP pile, at present, the CEP pile under vertical tensile, it has no related research results on controlling of crack resistance, which should be rapidly in need of further research and discussion [3].

\section{THE FEASIBILITY OF CONTROLLING THE CRACK RESISTANCE OF THE CEP PILE}

Compared to other forms of pile, the CEP pile due to the special structure itself of pile, so the uplift bearing capacity can be greatly improved, in the case of guaranteeing uplift bearing capacity, the CEP pile has some characteristic that can shorten the pile length, reduce the pile's number, avoid through some complex formation, saving time and material, etc. The CEP pile will gradually become the main form of uplift piles, that has potentially great economic value and social benefits, has the strong market competing ability, today, especially with rapid economic development, more strong vitality and development prospects is shown. However, how to solve the problem of controlling crack of uplift piles is another key issue in the study field of this.

The control of crack is the ability to resist crack for structure and elements. In the concrete structure, when external loads increase, it is mainly by increasing the section size of components or the dosage of steel to control cracks and deformation, but the method not only is uneconomical, but also increases the weight of structure itself, and makes limit for concrete structure [4]. Therefore, in order to make further develop to reinforced concrete structure, it is needed to be solved that the problem of poor tensile performance of concrete. The application of prestress for solving this problem provides a good way. If it is exerted that a certain compressive stress to concrete in advance, and to make it has no crack after tensile stress effect, so the defects of low tensile strength of concrete can be offset, the compressive stress exerted of concrete in advance is called prestressing.

At the condition of same parameters for the common pile and the CEP pile, the uplift bearing capacity of the CEP pile is greatly higher than the common pile, but due to the tensile performance of concrete is poor, so to consider the pile itself is not damaged before the soil, and crack resistance is lower, that is due to the lack of tensile bearing capacity of pile that the tensile failure is developed, or due to the lack of crack resistance, the result is crack exceeds the limitation, further effects durability. Therefore, as prestressed steel is embeded in the CEP pile, namely certain compressive stress is first imposed, no crack is developed under tensile stress effect, the defect of the lower tensile strength of concrete can be offset, while the cracks effectively controlled for uplife resistance of pile has been improved, so as to further it is determined that the reasonable range, quantity and specification of steel, etc.

The prestressed steel in the CEP pile, is accomplished mainly throughout steel prestressed and anchored at the end of concrete.With the continuous development of prestress technology, especially the recent 20 years, due to the material, the prestressed system and the development of construction technology, all kinds of new technologies, new methods and new design concept, that was applied, so it has made remarkable achievements, prestressed concrete structures were widely used in various kinds of structure. And with nearly half a century of trial and error, prestress of construction technology has been perfected, and with the continuous development of economy, it is widely used that different mechanical equipment in construction, construction of prestress has become more simple than before. It is proposed that prestressed concrete can save materials, reduce the quantity of steel and decrease the size of cross section of pile, reduce the weight of pile, at the same time also won't increase the budget for the whole project, and quality is reliable. Therefore, it has its feasibility in theory and construction technology that the CEP pile with prestressed improve crack resistance of pile.

\section{CONCLUSION}

Now, the CEP pile can be used as a effective way of uplife pile, but because of the tensile strength of concrete is lower, so under the vertical tensile, the problems existed is about controlling crack resistance. By setting the prestressed steel and controlling prestress magnitude, the cracks can be effectively controlled, at the same time, it also can be improved that the tensile bearing capacity of the pile. Feasibility by setting the prestressed steel for the CEP pile to effectively control the crack resistance of pile, it still needs further study on principles, methods, specifications of setting prestress, etc., it will be provided that the reliable basis on the study of uplift bearing capacity of the CEP pile.

\section{CONFLICT OF INTEREST}

The authors confirm that this article content has no conflict of interest.

\section{ACKNOWLEDGEMENTS}

This work is financially supported by National Natural Science Foundation of China (51278224).

\section{REFERENCES}

[1] Y. H. Li, and X. J. Gao, "The research of contrast test on uplift bearing capacity between squeezed branch piles and common piles", Henan University of Technology, vol. 29, pp. 391-395, Jun, 2010.

[2] H. Yuan, Y.Q. Zhang, Z. H. Qu, and H.D. Gao, "The experimental research of expansion pull-out performance on squeezed branch piles", The $16^{\text {th }}$ National Conference on Structural Engineering, China: Chengdu, 2008, pp. 378-380.

[3] J. Zhang, Y. Shang, and X. Lin, "The analyze of considering pulling force position effects the deformation of tension pile," Journal of Civil Engineering, vol. 38, pp. 102-106, July, 2005.

[4] J. S. Jin, Structure of Concrete, China: Wuhan, pp. 287-312, 2009.

\footnotetext{
Received: August 05, 2014

(C) Yongmei et al.; Licensee Bentham Open.
}

Revised: January 17, 2015

Accepted: January 20, 2015

This is an open access article licensed under the terms of the Creative Commons Attribution Non-Commercial License (http://creativecommons.org/licenses/by-nc/3.0/) which permits unrestricted, non-commercial use, distribution and reproduction in any medium, provided the work is properly cited. 